\title{
THE METHODS OF GIRLS ASY'ADIYAH ISLAMIC SENIOR HIGH SCHOOL IN WAJO TO OVERCOME LEARNING DIFFICULTIES AMONG THE FLUNKED STUDENTS
}

\author{
Hasmah \\ Sekolah Tinggi Agama Islam As'adiyah Wajo, Sengkang \\ Lapongkoda, Tempe, Wajo Regency, South Sulawesi 90912 \\ Email: hasmahwajo@gmail.com
}

\begin{abstract}
This article mainly concerned about factors that cause students to stay in class have difficulty learning in the subjects of Islamic Cultural History there are two factors, namely internal factors, and external factors. Slow learner students experience learning difficulties in Islamic Cultural History subjects due to internal factors in the form of health that is often disrupted, prenatal disorders, and low intelligence, also caused by external factors from the family environment. The learning difficulties of underachiever students in Islamic Cultural History subjects are influenced by internal factors in the form of no interest in learning in Islamic Cultural History subjects, causing students to lack attention, motivation, and lack of readiness in following the learning process.
\end{abstract}

Keywords: Cultural History, Experience, Difficulties, Intelligence

\section{INTRODUCTION}

Education has a very broad meaning, experts provide a variety of definitions. According to Hasbullah, education is 
a human effort to foster their personality following the values in society and culture, guidance or help provided deliberately by adults so that someone can become an adult. ${ }^{1}$

National Education System Law No. 20 of 2003 Chapter I Article 1 explains the notion of education as follows:

Education is a conscious and planned effort to create an atmosphere of learning and learning process so that students actively develop their potential to have spiritual, religious, self-control, personality, intelligence, noble character, and skills needed by themselves, society, nation, and country. ${ }^{2}$

Understanding education above has a different editorial but has the same elements - namely in the education process, there are processes of educating, educating, students, and educational goals.

Education is a very complex activity, ${ }^{3}$ not limited by formalities in the form of transfer of knowledge in the classroom conducted by a teacher to students but manifested in a variety of activities, various methods, and media. In this

${ }^{1}$ Hasbullah, Dasar - Dasar Imu Pendidikan (Cet.X; Jakarta: Rajawali Pers, 2012) p. 1.

${ }^{2}$ Republik Indonesia, Undang-Undang RI Nomor 20 Tabun 2003 tentang Sistem Pendidikan Nasional Bab I Pasal I (Cet. I; Jakarta: Indonesia Legal Center Publishing, 2009), p. 60.

${ }^{3}$ Mujamil Qomar, Kesadaran Pendidikan (Jogjakarta: Ar-Ruzz Media, 2012), p.15. 
context, everything that gives value to the benefits and meaning of life can be categorized as an educational activity. ${ }^{4}$

Every student has the same right in obtaining opportunities to achieve satisfying learning outcomes. But it cannot be denied that every student has differences. As a teacher who teaches at school every day, of course, it is not uncommon to have to deal with students who have difficulty in learning, it is very difficult to accept subject matter or who have problematic behavior that daily makes behavior and behavior that is not according to the rules. ${ }^{5}$

Achieving educational goals in the learning process is not easy. Many problems are often faced by teachers such as learning difficulties experienced by students. Learning difficulties experienced by students include difficulty accepting subject matter, being indifferent to lessons, not doing assignments and so on. These learning difficulties are one of the problems or problems that can hinder the achievement of learning goals or educational goals.

Mulyono Abdurrahhman classifies learning difficulties into two groups, namely learning difficulties related to development (developmental learning disabilities) and academic learning difficulties (academic learning disabilities). Learning difficulties related to development include motor and perception disorders, language and

${ }^{4}$ As'aril Muhajir, Ilmu Pendidikan Perspektif Kontekstual (Jogjakarta: Ar-Ruzz Media, 2011), p. 26.

${ }^{5}$ Muhibbin Syah, Psikologi Belajar (Jakarta: PT. Raja Grafindo, 2012), p. 21. 
communication, and learning difficulties in adjusting social behavior. $^{6}$

In general, what has been happening is that the grading system is designed with the provisions for class increase measured from the value or number in the report card achieved by students, as Nasution argues that "report card numbers form the basis of class promotion". Thus, the system that runs is adjusted based on the average value of children living in-class reports are low.

However, we need to realize that the fact that students get low scores needs to be researched and overcome. Children who stay in class need special attention and need to be given guidance so that students staying in class can get better achievements and class repetition is not repeated. The negative impact of students living in classes is very detrimental to students themselves because students will be two years in the same class so that students will feel excluded from their classmates. Not going up to class or staying class is a painful experience, so sometimes there is something that causes children to be embarrassed to repeat in the old class or learn with new friends who are under the age. This problem can cause students to drop out of school (drop out).

Based on data obtained in the field, it is known that in Madrasah Aliyah As'adiyah Putri Sengkang, Wajo Regency

${ }^{6}$ Mulyono Abdurrahman, Pendidikan Bagi Anak Berkesulitan Belajar (Jakarta: Rineka Cipta, 2009), p.11.

${ }^{7}$ S. Nasution, Berbagai Pendekatan dalam Proses Belajar dan Mengajar (Jakarta: Bumi Aksara, 2010), p. 66. 
there are still students living in classes, the provision of class residency in Madrasah Aliyah As'adiyah Putri Sengkang, namely not achieving Minimum Completeness Criteria (KKM) in 10 subjects and the presence of students in the learning process does not reach $75 \% .^{8}$ One of the subjects where the students live the class is not able to achieve the KKM value is the subject of Islamic Cultural History. The failure or inability of students to achieve the KKM score is an indication of learning difficulties.

The teacher in this case is responsible for fostering students to be as successful as expected. Conditions like this that cause the need for methods that focus their activities in helping students to be successful in the educational process that is being taken.

\section{GENERAL DESCRIPTION OF RESEARCH LOCATION}

Girl Asyadiyah Islamic Senior High School in Wajo is a medium-level formal education institution under the auspices of the As'adiyah Islamic Boarding School foundation located in the heart of Sengkang city, Wajo Regency. This school was established in 1970, which is now 49 years old. Since its establishment up to now, Madrasah Aliyah As'adiyah Putri Sengkang has experienced the replacement of Madrasah Heads nine times, namely: In 1970-1972 led by K.H. Hamzah Manguluang, 1972-1975 led by Badriah Samad, BA, 1975-

${ }^{8}$ Interview with Rosmilah, fifty years old. 
1978 led by Syahri Alam, BA., 1978-1980 led by KH. Abdullah Martan LC, 1980-1983 led by Dra. Syamsul Duha Adnan, 1983-1997 led by Dra. Hj. Manti DM., 1997-2007 led by Dra. Hj. Sitti Aminah Adnan, M.Ag, 2007-2018 led by Dra. Hj. Rosdianah HS., MM., And in 2018 until now it is led by Dra. Hj. Rosmilah Salih.

\section{FORMS OF DIFFICULTY LEARNING HISTORY}

Staying class is very undesirable by students, each student will try to learn optimally to get good achievements or grades each semester, to be able to continue learning at the next level and avoid class residency which is a disgrace for students. Even the school or madrasa itself will try so that none of the students who live class. However, the phenomenon of staying in the Madrasah Aliyah As'adiyah Putri Sengkang Regency in Wajo Regency still occurs, following Dra. Rosmilah head of Madrasah Aliyah As'adiyah Putri Sengkang, Wajo district:

Every school or madrasa does not want their students to stay in class, nor are we here, the Trustees in this Madrasah (Madrasah Aliyah As'adiyah Putri Sengkang, Wajo Regency) do not want our students to stay in class, but sometimes some students cannot be helped so the reason left behind is explained like in the last school year there were two of our students who had to stay the class. In the past few years, there have also been students who lived in classes. In Madrasah, we live in classes not happening every school year, we madrasa coaches always try so that no student lives in class.'

${ }_{9}^{9}$ Interview with Rosmilah, fifty years old. 
Students at the Aliyah As'adiyah Putri Sengkang Madrasah are decided to stay class if they do not meet $75 \%$ attendance and do not reach the Minimum Mastery Criteria (KKM) in 10 subjects.

Data found in the field shows that two students are living in the class, namely students with the initials SS and $\mathrm{H}$. Both students cannot reach the Minimum Mastery Criteria (KKM) value in several subjects including the subjects of Islamic Cultural History. The following forms of learning difficulties in the history of Islamic culture experienced by SS and $\mathrm{H}$. students

\section{Low Grade}

The problem experienced by SS students in Islamic Cultural History subjects is that SS is unable to achieve the Minimum Mastery Criteria (KKM) value set by the Islamic Cultural History Teacher. Minimum completeness criteria are the minimum value students must achieve. This was conveyed by KM. Kasyifah Ilyas, S.Pd.I Islamic Cultural History Teacher in the following interview:

"This SS has never been able to achieve the KKM score, the Minimum Completeness Criteria is the lowest value, the standard value that must be achieved by every student during the exam, as a reference for teachers to assess students' competencies, as a reference also for students preparing themselves in participating in learning because KKM is a measure of mastery of the material. SS in each of the exams both daily and 
semester tests never reach a standard score, continue to be low in the value of Islamic Cultural History subjects. SS students are always experiencing problems or difficulties in achieving standard scores. "10

The teacher training of Islamic Cultural History and the Deputy Head of Madrasah curriculum above explained that the achievement of the standard value or the Minimum Completeness Criteria for students was very important for each subject studied including the subjects of Islamic Cultural History. SS students in the subject of Islamic Cultural History always get low scores or below the Minimum Examination Criteria in each test that is tested by the teacher, both daily and semester tests.

\section{Weak Memory}

One type of learning difficulties experienced by SS students living in Madrasah Aliyah As'adiyah Putri Sengkang Regency, Wajo Regency is a weak or forgotten memory.

The statement from the Islamic Cultural History teacher regarding the weak memory experienced by the SS in learning Islamic Cultural History is reinforced by the SS homeroom teacher's statement that many subject teachers complained about the SS's condition. SS is very difficult to understand the lesson, has a weak memory, and often forgets. This is based on the following interview excerpt:

SS students indeed have difficulty in understanding the lessons, not in certain subjects such as the History of Islamic Culture but many because many subject

${ }^{10}$ Interview with Kasyifah, twenty-seven years old. 
teachers complained about the same thing. If the teachers get together during recess usually tell each other about the SS, some say that the SS is matengge mappahang, some say the SS is madodong mentong or makurappahang. ${ }^{11}$

Based on the data above which is the result of observations and interviews with Cultural History teachers, homeroom teachers, and students themselves who experience learning difficulties in Madrasah As'adiyah Putri Sengkang, then based on the above explanation it can be concluded that the type of learning difficulties History of Islamic Culture experienced by students is weak memory, often forget, or difficult to understand the lesson.

\section{Bad Performance}

From the observations and interviews above that, the form of learning difficulties experienced by SS students is a slow learner. This can be seen from the existing characters in the SS, the SS has an academic development under a predetermined standard, the SS has never been able to achieve the Minimum Completion Criteria value in each test that is followed both daily and semester tests. SS has a weak memory, hard to understand lessons, and easy to forget. SS also often does not attend classes or skip classes, which is why $\mathrm{SS}$ is determined not to graduate.

11 Interview with Kasyifah, twenty-seven years old 


\section{FACTORS OF LEARNING DIFFICULTIES}

Learning difficulties experienced by SS and $\mathrm{H}$, internal factors are categorized. Following are the results of research on internal factors that cause learning difficulties Islamic Culture History students to stay in SS class:

\section{Body condition}

The main causes of learning difficulties for SS and $\mathrm{H}$ students are health factors and prenatal factors. Health is an important factor in learning because the situation of students will greatly affect the effectiveness of learning. Thus the physical condition of students who do not allow to receive lessons due to illness or unhealthy will hinder learning because people who are sick will experience physical weakness. Likewise, unhealthy students will have difficulty learning because they are easily tired, sleepy, lost concentration power, and lack of enthusiasm. This was confirmed by KM. Kasyifah Ilyas, S.Pd.I teacher of Islamic Cultural History Madrasah Aliyah As'adiyah Putri Sengkang and $\mathrm{Hj}$. Junaedah stated that SS and $\mathrm{H}$ had prenatal disorders and were often ill. Prenatal factors, factors in the process of birth in which the baby experiences a condition of lack of oxygen during the birth process due to a prolonged or problematic labor process that causes oxygen transfer to the baby's brain is inhibited can be the cause of the child to be slow in learning or slow learner. ${ }^{12}$

${ }^{12}$ Krisna Indah Marheni, Art therapy bagi anak slow learner, Prosiding Temu Ilmiah X Ikatan Psikologi Perkembangan Indonesia ISBN: 978-602-1145-49-4, p. 157. 
Based on this, it can be concluded that one of the factors causing SS and $\mathrm{H}$ is slow in learning because of prenatal disorders and health problems.

\section{Intelligence}

Intelligence is the ability to learn, the ability of students to understand, know, or use abstract concepts. Students who can learn will be able to understand the learning material provided by the teacher and try to understand the learning material provided. Based on data obtained in the field $\mathrm{SS}$ and $\mathrm{H}$ learners have difficulty in understanding lessons in school. SS and H can learn below from their classmates.

Excerpts from interviews with Islamic Cultural History teachers and SS and H's grandmothers show that SS has a low level of intelligence. SS has difficulty understanding school lessons. SS and $\mathrm{H}$ have no attention and are not motivated to learn. This low understanding factor is one of the causes of learning difficulties experienced by SS and $\mathrm{H}$. students.

To overcome these problems the role of parents and teachers is needed. In this case, it is very important to approach or mentally coach the child so that the spirit of learning and getting along remains embedded in the child so that if the method is more intense between teachers and parents, then the child's mental state will not be awakened or formed by itself. This is clear and confirmed by Sutjipto 
Wirowidjojo in Slameto who stated that: the family is the first educational institution for children. ${ }^{13}$

\section{METHODS TO OVERCOME}

Students are only assigned one job that is learning. Students must learn. But not all students can learn well, some experience difficulties in the learning process. If students experience difficulties in learning such as being bored, not being able to concentrate is normal but cannot be tolerated. The following methods are used by Islamic Cultural History teachers in overcoming learning difficulties for students living in Madrasah Aliyah As'adiyah Putri Sengkang Madrasah:

\section{Data Collection}

Data collection aims to obtain data about a problem or the cause of a problem to occur so that an understanding is obtained and carried out directly, thoroughly, and systematically. To find the form of learning difficulties and the causes of learning difficulties for students living in Madrasah Aliyah As'adiyah Putri Sengkang class, namely SS and $\mathrm{H}$, a lot of information is needed. This information can be obtained in various steps.

One of the steps in data collection is done by Islamic Culture History Madrasah Aliyah As'adiyah Putri Sengkang teacher, namely direct observation of problematic objects, namely SS and $\mathrm{H}$. students. observing the results of the

13Slameto. Belajar dan Faktor-Faktor Yang Mempengarubinya, p. 62. 
assignments, daily tests, and semester tests of SS and H. class students. Another step used by Islamic Culture History teacher Sengkang Aliyah Islamic Madrasah girls in collecting data about the learning difficulties experienced by students living in SS class and $\mathrm{H}$ and its causes, namely interview and documentation techniques. ${ }^{14}$

\section{Data Processing, Diagnosis}

Data obtained from observations, interviews, and documentation as well as information from fellow teachers are then processed to diagnose, determine what forms of learning difficulties experienced by SS and $\mathrm{H}$ students, what factors contribute to the learning difficulties of SS and $\mathrm{H}$ students, factors main causes of learning difficulties SS and $\mathrm{H}^{15}$

\section{Prognosis}

Prognosis is the activity of preparing a plan or program that is expected to help overcome students' learning difficulties. Prognosis decisions are taken based on the results of the diagnosis, in the prognosis, the programmatic activities are carried out and the determination of assistance must be given to students to get out of the learning difficulties they experience.

The remedial learning program is used as one of the methods of the teacher of Islamic Culture History Madrasah Aliyah As'asiyah Putri Sengkang Wajo Regency in overcoming

\footnotetext{
${ }^{14}$ Interview with Kasyifah, twenty-seven years old

${ }^{15}$ Interview with Kasyifah, twenty-seven years old.
} 
learning difficulties for students living in SS and H. classes. The remedial learning program is an educational service provided to students to improve their learning achievement to achieve the criteria completeness specified.

\section{Evaluation}

The evaluation was carried out by Islamic Culture History Teachers after conducting remedial learning to determine the effectiveness of the learning process that has been done. The evaluation form given is in the form of a summative test to find out the level of students 'mastery of the subject matter, determine the value as material for students' learning progress reports living in class. ${ }^{16}$

In addition to the methods above that were carried out to overcome the difficulties of learning Islamic Cultural History of students living in class, Islamic Cultural History teachers also shared methods in the learning process, namely:

\section{Using a variety of methods}

Another method used by Islamic Culture History teachers in overcoming learning difficulties for students living in Madrasah Aliyah As'adiyah Putri Sengkang class in Wajo Regency is to use a variety of methods. In addition to the lecture method, the Islamic Cultural History teacher also uses the method of discussion, question and answer, group work, storytelling, concept maps and watching films together.

${ }^{16}$ Interview with Kasyifah, twenty seven years old 
The method most often used by Islamic Cultural History teachers among the various methods is the lecture method, then interspersed with questions before starting to glorify learning as a review of previous learners as well as questions in the middle of learning to attract the attention of students and questions at the end of learning. There is also a method of discussion and group work carried out as a distraction to support the activeness of students and establish a close relationship between students. The variation method used by the teacher is the concept map method used in the learning of Islamic Cultural History to make it easier for students to follow and understand the flow of history, students who will later make connections between one concept and another. The storytelling method is used to practice the courage of students to speak in front of the class. The most popular method for students is watching movies together, by watching students' films easily remembering events that occurred in history. ${ }^{17}$

The data above shows that Islamic Culture History teachers have tried to overcome the learning difficulties of Madrasah Aliyah As'asiyah Putri Sengkang students in Wajo District by using various methods such as lectures, questions, and answers, discussions, group work, concept maps, and watching films together. The use of the varied methods is intended to attract interest, attention, eliminate boredom,

${ }^{17}$ Interview with Kasyifah, twenty seven years old. 
bored, drowsiness of students when attending Islamic Cultural History learning.

\section{Humorous Interlude In Delivering Material}

To reduce the learning difficulties experienced by students, Islamic Cultural History Madrasah Aliyah As'asiyah Putri Sengkang teacher in Wajo Regency chose to use humorous techniques in the midst of delivering material. The use of humorous while delivering this material is done to reduce boredom and saturation of students. As explained by one of the teachers of Islamic Cultural History in Madrasah Aliyah As'asiyah Putri Sengkang, Wajo Regency as follow :

If in my opinion, the students are more enthusiastic and comfortable when I intersperse with humor in delivering the material, rather than continuing to deliver the material by the lecture method, then the children are quiet as if paying attention, at the beginning - at the beginning, they are paying attention but eventually they will get bored, tired if the conveyer not interesting, the problem is history is not like other lessons, this is a lesson in storytelling. ${ }^{18}$

Based on the results of the interview above it can be concluded that one of the other methods carried out by Islamic Culture History Madrasah Aliyah As'asiyah Putri Sengkang teacher in Wajo Regency in overcoming learning difficulties is to use humorous techniques in the midst of delivering material, this method is done to create a pleasant learning atmosphere so that the learning goals that have been

${ }^{18}$ Interview with Kasyifah, twenty seven years old

JICSA Volume 09 - Number 01, June 2020 
designed by educators can be achieved by all students especially students who have difficulty in learning.

\section{CONCLUSION}

In the learning process in Madrasah Aliyah As'adiyah Putri Sengkang, two students are living in class who have difficulty learning in the subjects of Islamic Cultural History. The form of learning difficulties experienced by live students, namely Slow learners and Underachievers, is based on the characteristics found in each student living in the classroom such as low grades, poor understanding, and poor performance, being bored and not concentrating in the following learning.

Factors that cause students to stay in class have difficulty learning in the subjects of Islamic Cultural History there are two factors, namely internal factors, and external factors. Slow learner students experience learning difficulties in Islamic Cultural History subjects due to internal factors in the form of health that is often disrupted, prenatal disorders, and low intelligence, also caused by external factors from the family environment. The learning difficulties of underachiever students in Islamic Cultural History subjects are influenced by internal factors in the form of no interest in learning in Islamic Cultural History subjects, causing students to lack attention, motivation, and lack of readiness in following the learning process.

The method of Islamic Cultural History teacher in overcoming learning difficulties of students living in class is 
to provide remedial learning which is done through the stages of diagnosing: data collection, data processing, diagnosis, prognosis, and evaluation. Remedial learning is given to students living in class based on the forms of learning difficulties experienced by each student living in class. Remedial learning given to slow learner students is individual learning while remedial learning is given to underachiever students, namely peer tutors. Another method used by Islamic Cultural History teachers in overcoming the learning difficulties of students living in class is to use a variety of learning methods and humorous interlude in delivering material.

\section{REFERENCES}

Abdurrahman, Mulyono, Pendidikan Bagi Anak Berkesulitan Belajar. Jakarta: Rineka Cipta, 2009.

Amerudin, artikel penelitian, Deskripsi Kesulitan Belajar dan Faktor Penyebabnya Pada Materi Fungi di SMA Islam Bawari Pontianak dan Upaya Perbaikannya. Artikel Penelitian, Pontianak: ttp, 2013.

Darsono, Max, dkk., Belajar dan Pembelajaran. Semarang: IKIP Semarang Press, 2000.

Destri Ratna Ma'rifah, Diagnosis Kesulitan Belajar Mahapeserta didik Pada Mata Kuliah Perkembangan Peserta Didik, Jurnal Pendidikan Biologi Indonesia, VOL 3, 2017.

Hamalik, Oemar, Proses Belajar Mengajar. Jakarta: Bumi Aksara, 2003. 
Hasbullah, Dasar - Dasar Ilmu Pendidikan. Cet.X; Jakarta: Rajawali Pers, 2012.

Indah, Krisna Marheni, Art therapy bagi anak slow learner, Prosiding Temu Ilmiah X Ikatan Psikologi Perkembangan Indonesia ISBN: 978-602-1145-49-4, h. 157.

Muhajir, As'aril, Ilmu Pendidikan Perspektif Kontekstual. Jogjakarta: Ar-Ruzz Media, 2011.

Nasution, S., Berbagai Pendekatan dalam Proses Belajar dan Mengajar. Jakarta: Bumi Aksara, 2010.

Qomar, Mujamil, Kesadaran Pendidikan. Jogjakarta: Ar-Ruzz Media, 2012.

Republik Indonesia, Undang-Undang RI Nomor 20 Tabun 2003 tentang Sistem Pendidikan Nasional Bab I Pasal I. Cet. I; Jakarta: Indonesia Legal Center Publishing, 2009.

Sri, Wahyuning, Andayani, Membina Anak Tinggal Kelas Sekolah Dasar Negeri Bendosari Kecamatan Gebang Kabupaten Purworejo Jawa Tengah. Naskah Publikasi, Purworejo: Program Pasca Sarjana Universitas Muhammadiyah Surakarta, 2012.

Sugandi, Ahmad, dkk., Teori Pembelajaran. Semarang: UPT MKK UNNES, 2000.

Sugihartono, dkk., Psikologi Pendidikan. Yogyakarta: UNY Press, 2007.

Syah, Muhibbin, Psikologi Belajar. Jakarta: PT. Raja Grafindo, 2012. 
The Methods of Girls Asy'adiyah Islamic Senior High School In Wajo....

Tenrijaja, Besse, Diagnosis Kesulitan Belajar PAI dan Solusinya pada Peserta Didik SD 265 Assorajang Kabupaten Wajo. Parepare: UM Parepare, 2017. 